\title{
¿Quién es consumidor a los fines de la protección procesal?
}

\section{Osvaldo Alfredo Gozaíni}

\section{Introducción}

Cada tiempo histórico se diferencia de otro por las sensibilidades que recibe de su gente. Son sentimientos que se distinguen por vocaciones, problemas y esperanzas. En cada lugar, la dinámica está influida por el vecino, lo que le ocurre, lo que él mismo transfiere, y así el mundo avanza con relaciones y continuas intercomunicaciones.

Decía Perez Luño ${ }^{1}$ en la presentación de una obra (muy recomendable para los estudiosos del derecho constitucional), ${ }^{2}$ que el ciclo cultural de la humanidad, en el que se inscribe el movimiento ilustrado, tuvo como valores-guía en el plano filosófico los ideales kantianos de la racionalidad, la dignidad, la emancipación y el cosmopolitismo, mientras que en el político-jurídico se expresaba en los consabidos ideales del «tricolor»: libertad, igualdad y fraternidad. Hoy el signo de los tiempos parece orientarse hacia otro tipo de sensibilidad. En las últimas décadas del siglo XX se están abriendo grietas en los valores que eran tenidos como sólidos cimientos de la cultura humanista occidental. Al racionalismo se le oponen ahora una serie de pulsaciones irracionales; el universalismo cosmopolita es combatido por particularismos nacionalistas de distinto signo y frente a la igualdad se reivindican y enaltecen los más insólitos rasgos diferenciales.

1 Antonio Perez Luño, "Las generaciones de derechos humanos», en: Revista del Centro de Estudios Constitucionales, N 10, 1991, p. 210 y ss.

2 Derechos Humanos y Constitucionalismo ante el tercer milenio, Ed. Marcial Pons, Madrid, 1996. 
La defensa del consumidor se enlaza directamente con la evolución del derecho y sus nuevas instituciones. Es un modelo destinado a encontrar respuestas modernas a conflictos derivados de esa mudanza de hábitos y costumbres en vinculaciones que actualmente son diferentes.

Las relaciones de consumo son, entonces, una categoría novedosa que no se adapta a la tradición de reglas sustanciales previstas para las obligaciones o los contratos; por eso, cada disciplina ha perseguido una suerte de replanteo para buscar respuestas más adecuadas para el equilibrio justo que, por vía de principio, se espera en todas las relaciones jurídicas.

En este terreno algo difuso por ser un derecho reciente, en evolución, y en la búsqueda de un perfil que lo singularice sin posibilidades de error, aparece el derecho procesal con sus reglas y principios, de alguna manera estancos y poco proclives a reaccionar con manifestaciones de verdaderos cambios.

Las preguntas que esperamos responder en este ensayo no son muchas, pero son las que se plantea toda persona común, que no comprende porque la justicia hace prevalecer un modelo técnico abstracto que no concilia con las necesidades del tiempo al que le toca asistir.

En pocas palabras: todos sabemos que el mundo ha cambiado las reglas de producción y comercialización de bienes, cosas y servicios; de igual modo, la mentada globalización, ha concentrado las fuentes de riqueza y ampliado los límites entre el bienestar y la desolación; el problema se agudiza en este siglo que ha comenzado con convulsiones que modifican absolutamente el comportamiento habitual de las personas: V.gr: destrucción de las «Torres gemelas", guerra en Afganistán, desconfianza generalizada, inseguridad física permanente, y en Argentina, el desastre provocado por el default que lo ha llevado a la desintegración económica y a un agrupamiento social que reclama por sus derechos por vías no tradicionales, merced a la intrínseca poca credibilidad de las instituciones judiciales.

¿Se puede seguir pensando que a las personas se les da justicia únicamente por los jueces? ¿Es necesario que el Estado asuma como deber no negociable ofrecer seguridad jurídica con reglas de derecho claras y permanentes? ¿Debieran ser los jueces, una instancia final para los conflictos que surgen de conductas atípicas?, en definitiva, ¿qué hace el derecho procesal? $¿$ Creerá que con el modelo procedimental que tiene puede responder a los cambios y reclamos sociales? ¿Las facultades del juez en el proceso resultan suficientes para emprender un rumbo valiente y decidido en post de la justicia para el caso concreto? ¿Se creerá, en realidad, que con lo que se tiene, se asegura la realización de los derechos sustanciales? 
En definitiva, haremos un diagnóstico de situación donde el punto central de la observación estará en responder si es el consumidor una persona diferente al hombre común, al punto tal que merezca una tutela diferenciada.

Si la respuesta fuera positiva, se deberá analizar el sistema procesal pensado en resolver esos conflictos, porque nos parece claro, que el modelo actual es totalmente insuficiente, más allá de su formalismo rígido y de la pereza natural que ponen los jueces para imprimir aceleraciones distintas a los tiempos previstos en esas reglas absurdas del discurrir procedimental.

"Para nosotros el derecho del consumidor esta consolidado. No solo en el reconocimiento jurídico que riene, sino también como ciencia autónoma que encuentra en las universidades un espacio propio de enseñanza. De todos modos, es conveniente repetir la evolución que claramente señalan los Stiglitz (padre e hijo) ${ }^{3}$ cuando indican que, el derecho del consumidor es un sistema global de normas, principios, instituciones e instrumentos de implementación, consagrados por el ordenamiento jurídico en favor del consumidor, para garantizarle en el mercado una posición de equilibrio en sus relaciones con los empresarios. De modo que en orden a la evolución de los sistemas jurídicos nacionales de protección de los consumidores, se pueden describir algunos eslabones suficientemente nítidos.

Una primera etapa, durante la cual las relaciones de consumo comienzan a revelar al consumidor como parte débil (masificaciones, desigualdades reales, desinformación, etc.), menesterosa de tutela jurídica, pero aún sin respuesta alguna del derecho positivo. Es el tiempo anterior a la reforma del Código Civil (1968) y a la sanción de las leyes de abastecimiento, lealtad comercial y defensa de la competencia.

Un segundo período, a partir de la vigencia de las citadas normas, permite diseñar un sistema de protección al consumidor, a través de soluciones que, aunque genéricas y no específicamente dirigidas a aquel fin, importan de todos modos un avance notorio en orden a la equidad en las relaciones de consumo: 1) las reglas de la justicia

3 Rubén S. Stiglitz, “Contratación privada y protección al consumidor», en: Defensa de los consumidores de productos y servicios, Ed. La Rocca, Buenos Aires, 1994. 
contractual, esencialmente de la buena fe y el abuso del derecho; 2) el régimen de responsabilidad objetiva por daños derivados de productos elaborados; 3) la prohibición de engaño a través de la identificación de mercaderías y publicidad comercial, el control de las ofertas con premios, y el régimen de garantías, y 4) el régimen de control de precios de la ley de abastecimiento, y la represión de conductas anticompetitivas de la ley de defensa de la competencia.

La tercera etapa en la evolución del derecho del consumidor, se inicia en Argentina con la vigencia de la Ley No 22.240, que desenvuelve notas que deben necesariamente caracterizar el derecho del consumidor como sistema, esto es, incorporar normas portadoras de soluciones: 1) de protección; 2) específicas; 3) preventivas; 4) colectivas; y 5) efectivas.»

\section{II. ¿Quién es consumidor?}

No resulta fácil establecer un concepto acabado sobre quien es consumidor. Los modelos legislativos difieren y mientras algunos optan por una lectura amplia que incluye a "todo ciudadano", otros prefieren restringir el alcance a la persona que adquiere bienes o servicios para darle un destino final.

Informa Lorenzetti ${ }^{4}$ que la noción abstracta aparece en la resolución de la Comunidad Económica Europea, de 1975, conocida como Programa preliminar: el consumidor es la persona a la que conciernen los diferentes aspectos de la vida social que pueden afectarle directa o indirectamente como consumidor. Es el ciudadano consumidor, que da pie a la famosa frase de John F. Kennedy, pronunciada como mensaje al congreso, sobre Protección de los intereses del consumidor, el 15 de marzo de 1962: «[...] todos somos consumidores [...]».

Tampoco en la idea se deja de lado el trazar distancias o posibilidades en quienes pueden o no ser consumidores, de manera tal, que cabe argumentar, que este es un derecho que solo alcanza a las personas físicas y no a las jurídicas, que se gobiernan por otras leyes particulares.

4 Ricardo Luis Lorenzetti, Defensa del Consumidor-Ley No 24.240, Rubinzal Culzoni, Santa Fe, Argentina, 1994. 
La Directiva 93/13 del 15 de abril de 1993 de la Comunidad Económica Europea sobre cláusulas abusivas en los contratos celebrados con consumidores se interpreta que "consumidor" es toda persona física que, en los contratos regulados por la presente directiva, actúe con un propósito ajeno a su actividad profesional (Art. $2^{\circ}$, inciso b).

La problemática no es baladí, porque de esa categoría dependerán las facultades para estar en juicio y constituirse en "justa parte», evitando los problemas de legitimación a los que nos referiremos de inmediato.

Finalmente, se ha planteado que la persona física protegida por su condición de "consumidor» es aquella que necesita equilibrar la relación comercial que se establece entre quien vende y el que adquiere. Por ello, no tienen consideración de consumidores quienes lo hacen con la única finalidad de adquirir, almacenar, utilizar o consumir bienes o servicios con el fin de integrarlos en procesos de producción, transformación, comercialización o prestación a otros.

El Art. $2^{\circ}$, párrafo final, de la Ley No 24.240 (texto según reforma de la Ley No 24.999) dice que: «No tendrán el carácter de consumidores o usuarios quienes adquieran, almacenen, utilicen o consuman bienes o servicios para integrarlos en procesos de producción, transformación, comercialización o prestación a terceros. No están comprendidos en esta ley los servicios de profesionales liberales que requieran para su ejercicio título universitario y matrícula otorgada por colegios profesionales reconocidos oficialmente o autoridad facultada para ello, pero sí la publicidad que se haga de su ofrecimiento».

Además, cabe señalar que existe una franja de consumidores que aparece como más débil, constituida por los jubilados, carenciados, niños o ancianos, - denominada subconsumidores - que, respecto a sus necesidades, y a la forma de satisfacerlas, merecen especial tutela. Ello no significa que quienes no forman parte de esa categoría especial, quedan excluidos de la tutela normativa del consumidor, máxime cuando la ley de la materia no efectúa tal distinción. ${ }^{5}$ 


\subsection{El consumidor como adquirente}

La adquisición de cosas, bienes o servicios para uso personal o familiar no necesita de un derecho distinto ni especial, porque cuenta en el Código Civil con el conjunto de derechos y obligaciones emergentes de los contratos de compraventa.

Por eso, entender que el adquirente sea un consumidor que merezca una tutela diferenciada, basada en esa única calidad, es insuficiente y violenta las reglas del sinalagma (equilibrio en las prestaciones recíprocas).

Dar una conclusión así, no obstante, no significa desconocer el derecho nuevo generado desde las relaciones de consumo.

La diferencia, entonces, no está en el ámbito de los derechos del comprador, ni de los que tiene el vendedor. Estas son reglas consabidas y quedan establecidas en la estructura general de las normas sustanciales.

El problema se encuentra en que esta es la filosofía individualista del siglo XVIII, que no proyecta la contratación más allá de la relación privada entre personas físicas y/o jurídicas. El contrato es ley para las partes, se afirma, y desde este paradigma, la igualdad y la buena fe constituyen los baluartes de esta teoría.

Pero estas reglas que privilegiaron la autonomía de la voluntad, en los hechos no fueron bastantes para lograr el equilibrio en las prestaciones. Los contratos con cláusulas predispuestas, las ofertas aparentes, la violación de los fines previstos en el negocio jurídico, entre otras disfunciones, provocaron una reacción necesaria que se manifestó en diversas cuestiones.

Ellas son resumidas por Rubén Stiglitz: " ${ }^{6}$ La desigualdad entre los contratantes, existente al tiempo del perfeccionamiento del contrato, o la sobrevienente en la etapa funcional, evidenció la necesidad de hallar mecanismos cuya finalidad apunte a la protección de quien ya es desigual en la etapa genética, o en buscar fórmulas conducentes al restablecimiento del equilibrio perdido.

El primero de los instrumentos al cual se acudió, ha sido el desarrollo del derecho imperativo.

El segundo, el de la reformulación de la función de las normas supletorias.

6 Rubén S. Stiglitz, "Defensa del consumidor y contratación bancaria y financiera», en: Derecho del Consumidor, No 9, Ed. Juris, Rosario, 1998. 
El tercero lo constituye la consagración de la relación de equivalencia, como un standard jurídico de subida trascendencia, en paridad de situación con la buena fe o el orden público.

El cuarto, decididamente resistido por los dogmáticos de la autonomía de la voluntad, y que atrapa en su formulación a los anteriores, es la revisión del contrato.

Todos estos mecanismos tuvieron como destinatarios genéricos a los débiles de la relación de negocios, pero más específicamente a la figura del consumidor final, caracterizada ya sea como persona individual o jurídica, ubicada en el tramo final del circuito constituido por la producción, distribución y consumo, ya que pone fin a la vida económica del bien o servicio".

La principal surge de confrontar que la pretendida igualdad no era real cuando el negocio estaba resuelto en todas sus proyecciones desde una sola de las partes. De este modo, la adquisición era a ciegas, o estaba absolutamente condicionada por las circunstancias.

«La autonomía privada que en otra época justificó el origen de las relaciones contractuales y eximía de indagaciones sobre la justicia de su contenido, encuentra como límite en el derecho del consumo al orden público económico de protección; reaseguro de la economía de mercado y garantía para prevenir iniquidades».?

Solo uno tenía el poder de la negociación; el otro adhería a esa oferta y quedaba sometido a sus reglas. ¿Dónde estaba el equilibrio? ¿Cuál era la autonomía de la voluntad?.

Con este elemento vital para resolver hacia el futuro, se observa que la condición de adquirente no basta porque el problema está masificado. Es decir, se multiplica en situaciones iguales que convierten a dicha categoría singular entablada entre quien compra y el que vende, en un fenómeno social dentro del que se inscriben las ahora llamadas relaciones de consumo.

Esta advertencia, hizo ver a algunos autores la aparición de un derecho del consumidor, diferentes a los derechos colectivos de los consumidores, transportando la idea a los orígenes divisionistas que distinguen entre derecho objetivo y derecho subjetivo.

7 C. N. Com., Sala B, 1999/02/23, in re: «Banco de Galicia y Buenos Aires c. L. H., P. M. y otros", en: La Ley 1999-E, 717 - DJ, 1999-3-840. 
Si trasladamos esta diferencia al tema que nos ocupa, puede compartirse con quienes sostienen que el derecho del consumidor es un sistema global de normas, principios e instrumentos de implantación en favor del consumidor. Los derechos del consumidor, al contrario, son modernamente la proyección individual del derecho del consumidor.

«En este aspecto, ha dicho la Corte Suprema de Justicia de la Nación que: La normativa emanada de la Ley No 24.240 está integrada con el plexo jurídico general y especial que regulan las relaciones que se establecen a partir de la actuación de personas físicas o ideales de naturaleza pública o privada que intervienen en la producción, distribución y comercialización de cosas o servicios, y las que se dan dentro del marco de las disposiciones de la Ley No 22.262. Tal integración sucede porque ambas legislaciones regulan la actividad de dichas personas aunque en diferentes actos y consecuencias». ${ }^{8}$

De modo que, si el adquirente tradicional no sirve para encontrar a un consumidor, hay que observar el contexto y las condiciones como se da esa relación de negocios.

En consecuencia, la importancia está en las relaciones de consumo, que como tales se pueden leer desde una perspectiva puramente objetiva; y otra que persigue afianzar principios y valores a trascender.

La objetiva resalta la idea de relación jurídica de consumo; la segunda hace énfasis en los sujetos de la relación y los fines que en ellos se reflejan, es decir, se refiere a la protección del consumidor.

Soto Castro ${ }^{9}$ encuentra una fórmula mixta que sintetiza las dos primeras definiciones, en otras palabras, toma en cuenta ambas, es ecléctica y es la que de mejor forma engloba el fenómeno, toda vez que hace referencia al objeto y sujetos (relación de consumo y protección del consumidor).

De igual modo Rubén Stiglitz ${ }^{10}$ explica que: «la aceptación de una definición objetiva pura excluye de la órbita del derecho del consu-

8 Del dictamen del Procurador General de la Nación, CSJN, 1999/03/31, in re: "Retamar, María E. c. Moño Azul S.A.», en: RCyS, 1999-773 - ED, 183-469.

9 Rolando Soto Castro, El problema de la ciencia del derecho frente al problema del derecho del consumidor, Madrid, 1987, passim.

10 Rubén S. Stiglitz, "Defensa del consumidor [...]», op.cit. 
midor la preocupación finalístico-subjetiva que debe orientarlo. De hecho, el derecho del consumidor no se limita a regular la relación jurídica del consumo, per se. Ésta solo recibe tratamiento especial -que la distingue de las comerciales y civiles- porque uno de sus sujetos es considerado "parte vulnerable». No hay duda de que la relación jurídica de consumo es el objeto del derecho del consumidor. Mas el objeto, por sí solo, no se presta para describir el fenómeno como un todo, a no ser como agregado a un referencial subjetivo. La subjetivación del derecho del consumidor no basta como parámetro para definirlo. Aunque ese fue el camino del derecho mercantil, que partió de una concepción subjetiva, de un ius mercatorum, para un derecho de los actos de comercio (criterio objetivo), este no es el caso del derecho del consumidor que necesita -inclusive para su afirmación- del elemento personal indicador de la vulnerabilidad de su tutelado y de su contenido finalístico funcional.

Al contrario de la objetiva, la definición teleológico-subjetiva se centra en la figura del consumidor como ser vulnerable, que merece cuidados especiales del legislador y del intérprete. No es de hoy que el derecho plantea la necesidad de que los más débiles reciban un tratamiento diferenciado en la ley, exactamente como forma para restablecer el equilibrio con los más fuertes. Se trata, pues, de un esfuerzo en el sentido de restablecer la igualdad entre los sujetos.

Por ello, si el criterio subjetivo es el mejor para la elección terminológica de la nueva disciplina (derecho del consumidor), no lo es para definirla, porque podría llevar a creer que el consumidor esta protegido en todas sus relaciones; cuando en realidad, la tutela especial solo le es facilitada en razón de y en la relación jurídica de consumo".

\subsection{El consumidor como la parte débil en las relaciones de consumo}

Siguiendo la anterior argumentación, cabe agregar que si la condición de comprador es insuficiente para referir a un consumidor, entonces habrá que superar el obstáculo dirigiendo la atención al objeto que entre las partes conciertan.

De este modo, la relación de fuerzas y conocimientos que ellos tienen al tiempo de contratar o de vincularse, es diferente al concepto acuñado en la filosofía individualista que creía que los sujetos eran económica- 
mente iguales y en paridad de condiciones para negociar. En los hechos, no existe esa presunta igualdad, todo lo contrario, hay un marcado desnivel que el derecho del consumidor pretende igualar protegiendo a la parte más débil del negocio.

Pero ese negocio no es uno cualquiera, sino el que se da en las relaciones de consumo, de modo tal que el vínculo queda establecido entre empresario y consumidor.

De alguna manera, se deduce que la inferioridad emergente requiere de acciones proteccionistas que persigan compensar la diferencia entre fuerzas.

"La tutela o protección de la confianza responde a un criterio general en el que se inspira el legislador, que no está solamente previsto para superar el conflicto entre la voluntad y su manifestación, sino que ha terminado por afirmarse en un concepto integral de aquella, en el sentido de que el negocio o manifestación de la voluntad constrińe, no porque así se ha querido sino principalmente porque el otro contratante ha creído cuanto se le ha dicho. Esta tutela de la confianza se basa especialmente en la valoración objetiva de las situaciones, cuando el interesado (el consumidor), ha tenido motivos para fiarse de que el fabricante del producto le iba a entregar la mercadería correcta y adecuada para la finalidad que perseguían. ${ }^{11}$

Si alguien cree que es un paternalismo exagerado que violenta el principio de igualdad formal, de raigambre constitucional, y consagrado en las disposiciones del Código Civil, no estaría errado en la apreciación objetiva de las cosas; pero lo cierto es que alguien se hace consumidor por necesidad y no por voluntad. Podrá serlo en bienes no necesarios o imprescindibles, sin embargo, ello no desvirtúa la debilidad manifiesta que expone en su dimensión.

Se ha dicho que: "La superioridad técnica en que se encuentra el profesional con relación al cliente en el ámbito de la especialidad propia de aquel involucra conceptos que privilegian el favor débilis y

11C. N. Com., Sala B, 1985/09/25, in re «Rincón de Avila, Soc. en Com. por Accs. c. Cooper. Argentina, S. A. y otros", en: La Ley No 1986-C, 6, con nota de Rubén S. Stiglitz y Gabriel A. Stiglitz. 
conduce a colocar en primer plano la noción de consumidor, ya sea de cosas o de servicios". ${ }^{12}$

En consecuencia, la protección al débil fomenta cubrir las desventajas de quien no esta informado suficientemente sobre lo que adquiere; o huelga en él una experiencia aquilatada en el tema de la comercialización del bien o del servicio; o le falta profesionalidad; y en definitiva:

"Está de "este lado del mostrador", vale decir, ajeno al proceso de producción y distribución, sin conocimientos ciertos sobre costos; forzado «a creer», a confiar, a aceptar los precios y las calidades que se le ofrecen; no participa del proceso de fabricación del bien o de organización del servicio y desconoce, por lo común, los costos y variables». ${ }^{13}$

«En los contratos de adhesión, la protección de la parte más débil de la relación se sustenta en una suerte de "presunción de ignorancia legítima», razón por la cual su interpretación se rige por el principio "Contra preferente», directiva válida según lo establecido por los arts.: $953^{\circ}, 1071^{\circ}, 1198^{\circ}$ del Código. Civil y $218^{\circ}$, inc. $3^{\circ}$, del Código. de Comerciom. ${ }^{14}$

Claro está que se dan por supuestas estas fortalezas en el productor de los bienes o servicios, y es por eso que dicha superioridad que le permite "fijar las reglas», necesita igualarse con mayores deberes y compromisos hacia quien los adquiere o consume.

"Si bien la jurisprudencia es numerosa para esclarecer el alcance de la regla de igualación, el deber de seguridad del vendedor es una pieza importante para mostrarlo. Se ha dicho que sobre el vendedor pesa una responsabilidad contractual, si se trata de quien vende mercaderías de un ramo determinado y que tiene un giro comercial o de negocio de esa naturaleza, por lo que asume una obligación de seguridad o

12 C. N. Civ., Sala H, 1995/06/21, in re: "Gutiérrez, María E. c. Intermedics Inc. y otros", en: La Ley No 1997-E, 1007 (39.771-S).

13 Ricardo Luis Lorenzetti, Defensa [...], op.cit.

14 C. N. Fed. Contencioso-administrativo, Sala II, 1999/03/04, in re: «Ombú Automotores S. A. c. Secretaria de Comercio e Inversiones", en: La Ley 2000-B, 318. 
de garantía de que la cosa vendida no causará daño al comprador o a sus bienes, por causa o defecto o vicio que la tornen nocivan. ${ }^{15}$

En situación de conflicto, esta "igualdad de armas» (paridad de las partes en las posibilidades de defender los derechos en el proceso) se fundamenta en la función social que debe tener el proceso, y en el rol activo de la función jurisdiccional.

Esto significa que, aun otorgando al derecho del consumidor una protección diferenciada, ella se debe integrar en el litigio y lograr que aquella interpretación no se confunda ni limite cuando se mida la controversia en los carriles clásicos del proceso jurisdiccional.

Aun siendo un proceso constitucional aquel que desenvuelve el derecho del consumidor, la bilateralidad común del proceso ordinario debe existir. Pero la igualdad se consigue, únicamente, si el juez presta atención al contenido de las pretensiones en lugar de anteponer aquellos criterios individualistas que han regido la controversia judicial desde hace muchos años.

Por otro lado, el proceso judicial es una garantía constitucional. Preexiste al conflicto y es la reserva de justicia que tiene asegurada cualquier persona cuando encuentra que sus derechos están afectados. Esta garantía puede ser vista desde un modelo estanco y simple, que asegura el derecho de defensa en juicio y con ello, dejar en manos de las personas el ejercicio activo de esa defensa y en el poder del Estado la facultad de ofrecerle un instrumento, medio o lugar donde debatir en igualdad de condiciones y bajo un sistema de absoluta imparcialidad. $\mathrm{O}$ bien, se puede exigir del Estado algo más, es decir, que la justicia que ofrece sea útil y efectiva. Que no se destine a un formalismo simplista de dar $u$ ofrecer el instrumento o medio de debate, sino que esos jueces estén atentos y vigilantes al contenido de la contienda, para dar una herramienta suficiente, y una actividad basada en la prudencia, donde la oportunidad y la justicia deben llegar juntos. Es decir, el proceso judicial es una esperanza que no se puede desvanecer por su ineptitud para llegar a tiempo con sus respuestas, o por la necedad que manifiesta con las nuevas conquistas sociales.

Pero, no pretendemos que esa ventaja diferencial que tiene el consumidor, sea un elemento de prejuzgamiento que anticipe una sentencia favorable.

15 Cfr. J.A., 1994-II, 182. 
Podemos reconocer aquí, el riesgo de una actuación parcial del juez, que se concretaría si él ejercitare sus poderes en el interés exclusivo de una de las partes. Mas el riesgo de la parcialidad que ronda al juez, queda eliminada si los intereses en conflicto son argumentados y probados en base a las reglas distintas que tiene el derecho del consumidor.

En los hechos se trata de pura interpretación, de forma tal que quienes persiguen atar las manos al juez en la investigación de la verdad, no advierten que es pagar un precio demasiado alto por la prevención de un peligro que, aun sin tal exorcismo (el ser eventualmente parcial), normalmente permanece en "estado de peligro" y solo en casos excepcionales se convierte en daño actual.

Por otra parte, la interpretación «en favor del consumidor» está consagrado legalmente, y se ha manifestado en distintos precedentes, algunos de los cuales, enunciamos a continuación. Por ejemplo, se ha dicho que: «La cláusula contractual que delimita la responsabilidad del banco, al contemplar que este garantiza únicamente la integridad exterior de la caja de seguridad, sin responder por los objetos depositados, no debe tenerse por escrita por importar una renuncia anticipada de derechos del cliente en los términos de la Ley de protección del consumidor No $24.240 »{ }^{16}$

Asimismo, en el contrato de caja de seguridad el cliente es adherente y consumidor, por lo cual, se encuentra en situación de debilidad jurídica en la relación contractual y con la imposibilidad de cuestionar e intentar modificar el contenido de las cláusulas predeterminadas o predispuestas por el otro contratante, pues solo puede rechazarlas o aceptarlas sin debate alguno». ${ }^{17}$

También se sostiene que: «La tutela del consumidor - parte no proponente de un contrato de participación en círculos privados para la adquisición de bienes muebles, con cláusulas predispuestas- confrada a la autoridad de control (Inspección General de Personas Jurídicas), exige de ésta que vele por ello como respuesta al desequilibrio producido, consecuencia de la forma de contratación descripta que impide, o al menos dificulta en grado extremo, verificar a los participantes de estos círculos la regularidad de procedimientom. ${ }^{18}$ 
En los contratos de tarjeta de crédito el usuario del servicio se encuentra en una situación de desigualdad estructural en la relación con el emisor. Por ello, la empresa emisora tiene la obligación de alertar al adherente, y ponerlo al tanto de las características del servicio que se obliga a brindarle, pues la información es un bien apreciado que tiene valor jurídico y, consecuentemente, protección jurídica. Asimismo, el Art. $2^{\circ}$ de la Ley No24.240 crea obligaciones respecto a los proveedores de servicios por el solo hecho de prestarlos a consumidores o usuarios de manera profesional. ${ }^{19}$

Esto se ha resuelto así porque no puede admitirse que para negocios de la vida diaria, como es la suscripción a un sistema de tarjeta de crédito, el consumidor deba estudiar e interiorizarse de un lenguaje innecesariamente asentado en términos y expresiones ambiguas. Ello, pues la lealtad contractual recíproca veda la utilización de cláusulas con apariencia de legitimidad, pero con una sustancia marcadamente abusiva (mismo fallo anterior).

En síntesis, dado que el contrato de tarjeta de crédito se encuentra celebrado entre un comerciante profesional y un consumidor, rige el Art. $4^{\circ}$ de la Ley No 24.240, que garantiza el derecho de este a obtener información veraz, detallada, eficaz y suficiente sobre el negocio que realiza. Por ello, en ausencia de normas específicas sobre la emisión y uso de tarjetas de crédito, las medidas generales de protección al consumidor adquieren importancia particular, pues su objeto es garantizar el reparto equitativo y justo de los riesgos y el respeto de sus derechos" (mismo fallo anterior).

El remedio más eficaz contra el riesgo de la parcialidad no consiste en argüir obstáculos en la investigación de la verdad. Consiste sí, en imponer al juez el respeto escrupuloso de la contradicción en la actividad instructiva y la estricta observancia del deber de motivar sus decisiones, mediante el análisis cuidadoso de la prueba producida y la indicación de las razones de su convencimiento acerca de los hechos.

\subsection{El consumo final o en propio beneficio como característica}

Para ser consumidor se necesita que el bien, producto o servicio que adquiere o utiliza, sea para uso propio o familiar y no tenga transmisiones

19 C.N. Com., Sala B, 1998/04/28, en: La Ley No 1998-C, 624. 
sucesivas. Es decir, que la relación de consumo tenga al adquirente como destinatario final.

Tal es la definición del Art. $2^{\circ}$ del Código Brasileño de Defensa del Consumidor que establece: «Consumidor es toda persona física o jurídica que adquiere o utiliza productos o servicios como destinatario final».

Este es un concepto eminentemente económico, porque caracteriza la condición de consumidor en la persona que obtiene bienes, o contrata la prestación de servicios cerrando la cadena que vincula las relaciones de consumo. Pero la adquisición o el uso que obtenga de dichos bienes, productos o servicios, debe resolver una necesidad propia, más no satisfacer el desarrollo de otra actividad negocial, porque de así resultar, no se es consumidor.

La idea central está en que lo adquirido o contratado no vuelva a ser comercializado, porque la cosa o el bien se consume con el último receptor. Además, queda incorporada en esta noción, la identificación entre destinatario final con consumidor no profesional (esto es: aquel que produce, comercializa, distribuye o presta servicios) creando una presunción que iguala a las partes en el intercambio.

Esto quizá sea un error, porque las personas jurídicas podrían ser consumidores y no así quienes se califiquen como profesionales.

La crítica que se formula contra esta definición proviene de sectores que interpretan al consumidor como una «categoría social», una clase de personas que puede adquirir y tomar una determinada posición dentro de un contexto determinado de la sociedad.

Sostiene Guido Alpa: ${ }^{20}$ "este concepto encierra componentes sociológicos y psicológicos que debieran abstenerse de aplicar, con el fin de permitir la consagración del derecho al consumidor. Igualmente, se procura abstraer consideraciones de orden literario o filosóficas, que resultan relevantes para analizar otras situaciones de la relación de consumo como son la publicidad o la difusión de la oferta».

Sin embargo, es la corriente que predomina en las legislaciones mundiales. Por ejemplo, la ley Sueca del Consumidor (1973) lo concibe como la persona privada que compra una mercadería, principalmente destinada a satisfacer un uso privado, y que es vendida en el ámbito de la actividad

20 Guido Alpa, Constitución y progreso, Ed. Bosch, Barcelona, 1984. 
específica del comerciante. En México (1976) se lo define como aquel que contrata la prestación de servicios o la adquisición de bienes para su uso o disfrute.

Nuestro país consagró en el artículo $1^{\circ}$ de la Ley No 24.240 que:

"Se consideran consumidores o usuarios, las personas físicas o jurídicas que contratan a título oneroso para su consumo final o beneficio propio o de su grupo familiar o social [...]"

De este modo, la condición de consumidor depende de hechos concretos como son la adquisición o locación de cosas muebles; el requerimiento de servicios, o la compraventa de inmuebles destinados a vivienda. ${ }^{21}$ Por ello, una estimación abstracta que piense en una protección genérica de los derechos del consumidor es posible solo como programa de acción política, o para indicar deberes del Estado tendientes a fomentar obligaciones concretas en su accionar en favor del consumidor.

«La jurisprudencia sostiene que, a los fines de la aplicación de la Ley $\mathrm{N}^{\circ} 24.240$, son consumidores las personas físicas o jurídicas que adquieren, utilizan o disfrutan bienes o servicios como destinatarios finales -en el caso, persona jurídica que adquirió un rodado para traslado de sus miembros y empleados-, ya sea a título personal, familiar, social o de su círculo íntimo". ${ }^{22}$

En el terreno judicial (dentro del campo de la interpretación jurídica del conflicto), no se puede perder de vista ambos enunciados. De un lado, porque existe un imperativo de proteger al consumidor en sus relaciones de consumo; $y$ por otro, para resolver la responsabilidad del Estado y demás obligados en la cadena del consumo respecto a sus respectivos deberes.

«La noción concreta depende del tipo de prestación o de producto a que se refiere. $Y$ puede haber pluralidad de nociones concretas, que aluden al adquirente, al consumidor final, al cliente. Y la noción

21 Cfr. Art. 10, Ley No 24.240.

22 C.N. Com., Sala A, 2000/1 1/21, in re: «Artemis Construcciones S. A. c. Diyón S. A. y otro», en: La Ley No 2001-B, 839 - DJ, 2001-2-345. 
legal, que en la ley argentina recoge la noción concreta de consumidor, puede ampliar o restringir su ámbito de aplicación, según la finalidad propia o razones de política legislativa [...]. La noción de consumidor final está relacionada con la de "destinatario final", tomada del ámbito del transporte: trata de manifestar gráficamente una idea básica para la noción, esto es, que adquiere los bienes o servicios para utilizarlos o consumirlos él mismo, y que, en consecuencia, esos bienes o servicios quedan detenidos dentro de su ámbito personal, familiar o doméstico, sin que vuelvan a salir al mercado. De allí que el adquirente pueda efectuar, sin dejar de ser consumidor final, pluralidad de transmisiones, respecto de los bienes adquiridos, dentro o fuera del ámbito doméstico, siempre que «sean ajenas a una actividad económica dentro del mercado", que se trate de transmisiones ajenas «al mercado de esos bienes». Es entonces consumidor final quien adquiere un bien para regalarlo, aunque el regalo no sea a un familiarm. ${ }^{23}$

No obstante, cabe agregar que si bien quedan fuera de este concepto aquellos que sin constituirse en destinatario final, adquieren, almacenan, utilizan o consumen productos o servicios con el fin de integrarlos en procesos de producción, transformación, comercialización o prestación de terceros, tal circunstancia no excluye de la regulación legal a quienes con ellos contratan cuando el destinatario de la producción es el consumidor.

\subsection{El cliente}

El concepto de cliente puede asumir una interpretación amplia y colegirse como aquel que tiene habitualidad de consumo en un comercio determinado; o precisarse desde un ángulo más restricto y comprender a la clientela, en el sentido de todas las personas a quienes se formula la oferta de bienes y servicios con la idea de capturar el interés en la adquisición o contratación; o también, en un foco más acotado que se limita a los compradores de un negocio particular.

En el primer caso, hay confusión entre cliente y consumidor; en el segundo, la posición genérica supone acentuar los deberes del productor, fabricante o vendedor.

23 Ricardo Luis Lorenzetti, Defensa [...], op.cit. 
«Por ejemplo, el cliente de un banco es consumidor y se encuentra en situación desfavorable en el sistema de acceso a la contratación de servicios. En este supuesto, el deber de buena fe -inherente a todo contratante- es más riguroso respecto del que predispone del bien - en el caso, la entidad bancaria que celebró un contrato de caja de ahorro con débito automático- que del consumidor, pues este último carece de facultades para introducir cambios en las cláusulas pactadas". ${ }^{24}$

Además, no debe de olvidarse que la razón de ser de la norma del Art. $42^{\circ}$ de la Constitución Nacional se encuentra en la necesidad de suministrar al consumidor los conocimientos de los que carece a fin de permitirle elegir, en forma racional y fundada, el bien o servicio que pretende contratar, y así disminuir la desigualdad de conocimientos que, naturalmente, existe entre quien concibe y publicita un producto o servicio y quien lo puede adquirir.

Cuando el cliente adquiere es consumidor; si no lo hace, puede también serlo si al concepto se le asigna una amplia dimensión que ocupe una pluralidad de nociones concretas sobre el significado del término consumidor.

En la oferta de bienes, por ejemplo, no se hace distinción entre quien "mira la vidriera» $y$ "quien entra para comprar", porque si en ella aparece una marca solapada para buscar la tentación, no obstante, el hecho de que uno de los signos o marcas débiles se encuentre difundido y acreditado en plaza, no hace otra cosa que alejar más todavía la posibilidad confusionista. En efecto, el público consumidor que ya conoce el producto y sus calidades, sabrá distinguirlo del que se pretende registrar y es en definitiva el interés del cliente el que se debe resguardar. ${ }^{25}$

En ocasiones, el cliente es consumidor porque ha contratado la atención de servicios (es usuario de ellos), y en consecuencia, más que de un consumo propiamente dicho, se trata de establecer el deber de cumplir con las prestaciones prometidas evitando acciones defraudatorias con la finalidad del negocio.

24 Cfr. C. N. Fed. Contencioso-administrativo, Sala II, 2000/08/22, in re: "Lloyds Bank Ltd.", en: La Ley No 2001-A, 479).

25 C. N. Fed. Civ. y Com., Sala III, 1991/12/13, in re: «Juan C.Beviglia c.C. Lemos y E. Chedas. y otro», en: La Ley No 1992-D, 144 - DJ, 1992-2-666. 
«En el contrato de caja de seguridad el cliente es adherente y consumidor, por lo cual, se encuentra en situación de debilidad jurídica en la relación contractual y con la imposibilidad de cuestionar e intentar modificar el contenido de las cláusulas predeterminadas o predispuestas por el otro contratante, pues solo puede rechazarlas o aceptarlas sin debate alguno». ${ }^{26}$

En líneas generales, la noción de cliente opera en la dimensión amplia que trae la idea de consumidor; puede ser: «un concepto legal que acoge a "tipos de consumidores", en el sentido de requerir cierta inferioridad o debilidad, carencia de poder de negociación, "consumidores marginales", pobres, etc. [...] ello no aparece explicitado en la Ley No 24.240 , de donde es la mera noción de consumidor la que implica una presunción legal de que todas las personas incluidas en ella -en la noción-, vale decir todos los consumidores a los que alcanza, están en la situación de inferioridad que ha originado la intervención del legisladorn. ${ }^{27}$

El concepto de "cliente-consumidor" aparece recogido en la jurisprudencia francesa para quienes «el consumidor es aquel que utiliza las mercancías no solamente para la satisfacción de sus necesidades personales, sino también para sus necesidades profesionales». ${ }^{28}$

Es decir, que se vincula la oferta con el destinatario, sin importar la condición de consumidor final, ni la profesionalidad del adquirente.

«En el seno de esta noción —dice Acosta Estévez- se incluye a los posibles clientes de un empresario, independientemente de que ellos actúen o no en calidad de empresarios: para ser consumidor no es que adquiere los bienes o servicios para su uso particular».

«Igualmente, dentro de la noción de cliente se incluyen a todos aquellos que contratan con un empresario para adquirir los bienes o servicios ofrecidos por él, tanto si la adquisición la realiza para atender sus

26 C. N. Com., Sala A, 1998/06/25, in re: «Haydée A. Flojeras y otro c. Banco Quilmes", en: La Ley No 1998-E, 156.

27 Ricardo Luis Lorenzetti, Defensa [...], op.cit.

28Sentencia del Tribunal de Grande Instance de Estrasburgo - 1973/11/15-en: Revue Trimestrielle de droit commercial, 1974, p. 142. 
necesidades privadas, como si se hace dentro del marco de una actividad empresarialm. ${ }^{29}$

Coincide con la ilustrativa reflexión de Santos Briz ${ }^{30}$ cuando indica que: «la fuerza interna de la voluntad negocial disminuye cuando se trata del cliente anónimo del gran público. El particular se siente impotente ante el gran establecimiento mercantil o industrial, y en lugar de la decisión tomada con previsión responsable de las consecuencias, se coloca en el papel pasivo de dejarse llevar a una relación jurídica por otros preformada e impersonal».

\subsection{Las personas jurídicas como consumidores}

En los términos desarrollados hasta ahora se constata que la noción de consumidor recoge varias ideas que resumen una finalidad común: proteger y tutelar a quien se encuentra en sus relaciones cotidianas de consumo (es decir, al consumidor medio típico) en una posición de inferioridad.

Este encuadre no elude considerar como consumidores a las personas jurídicas porque ellas también realizan todo tipo de contratos de locación, aseguramiento, operaciones bancarias, contratos de transporte, o con agencias de viaje, etc. Es decir, son consumidores finales como el consumidor medio típico que antes referimos.

De este modo sostiene la jurisprudencia que: «La Ley No 24.240 de defensa del consumidor, es aplicable respecto de la persona jurídica que adquirió a título oneroso un automotor para satisfacer las necesidades de su empresa comercial —en el caso, traslado de sus miembros y empleados-, pues reviste el carácter de consumidor o destinatario final del bien». ${ }^{31}$

Asimismo, la persona moral que contrata para satisfacer sus propias necesidades o de las de su grupo, sin resultar vinculado en forma profesio-

29 Rodrigo Bercovitz- R. Cano, «Ámbito de aplicación y derechos de los consumidores en la Ley general para la Defensa de los Consumidores y Usuarios», en: Estudios jurídicos sobre protección de los consumidores, Ed. Tecnos, Madrid, 1987.

30 Jaime Santos Briz, Los contratos civiles. Nuevas perspectivas, Ed. Comares, Granada, 1992.

31 C. N. Com., Sala A, 2000/11/21, in re: «Artemis Construcciones S. A. c. Diyón S. A. y otro", en: La Ley No 2001-B, 839 - DJ, 2001-2-345. 
nal o empresarial con el hecho o cosa de la adquisición, es igualmente un consumidor final.

Pero este no es un criterio absolutamente seguido por la doctrina. Bercovitz y Cano sostienen que: «las personas jurídicas no pueden ser destinatarios finales de bienes o servicios, y por ende no pueden ser considerados como usuarios o consumidores. Ello así, en la medida que las adquisiciones que realizan, al menos en la generalidad de los casos, no son bienes para sí, para su consumo personal o beneficio, y menos aun para el grupo familiar o social». ${ }^{32}$

El reconocimiento de las personas jurídicas como consumidores supone una diferencia en la forma de interpretar el fenómeno al cual se dirige el derecho a obtener una protección preferente. Se privilegia la debilidad en la contratación sistemática sin atender la profesionalidad del adquirente o usuario.

De algún modo, expone la distancia que tiene América respecto a Europa en la forma de establecer la tutela judicial.

"La evolución en Europa del derecho del consumidor parece que tiene lugar con menos dificultades, principalmente debido a la existencia de ciertas teorías tradicionales, como la de los vicios ocultos, que ya permitían una cierta protección al consumidor. Mientras que en los Estados Unidos la aparición del derecho del consumidor se desarrolla a partir de una perspectiva individualista y reparadora (protección del individuo-consumidor hasta llegar al público-consumidor), en Europa la evolución se produce como un esfuerzo mucho más por tutelar al público de una manera general, que propiamente por reparar los daños sufridos por consumidores individuales». ${ }^{33}$

\subsection{El usuario como proyección del derecho colectivo}

La insuficiencia de la noción de adquirente de cosas, bienes o servicios con el fin de satisfacer necesidades personales o familiares, es evidente

32 Rodrigo Bercovitz- R. Cano, "Ámbito de aplicación [...]", op. cit.

33 Antonio H. Benjamín, "Derecho del consumidor", en: Defensa de los consumidores de productos y servicios, Ed. La Rocca, Buenos Aires, 1994. 
cuando se trata de resolver la situación de los que tienen esos objetos puestos en el comercio, pero sin haberlos comprado en forma directa, a pesar de ser quienes los utilizan o aplican para sus necesidades.

La inteligencia que se persigue conseguir en la interpretación jurídica del suceso, proviene de establecer deberes emergentes de la condición de productor $\mathrm{u}$ oferente de los bienes o servicios. De este modo, el derecho del consumidor advierte que la protección se confiere tanto al que adquiere (carácter jurídico) como al que usa o consume los bienes o servicios que obtiene (carácter material).

Según Lorenzetti, la Ley No 24.240 alude a consumidores reales o actuales, y no meramente potenciales, como son aquellos que pueden ser perjudicados, sin llegar a la celebración de un acto jurídico, por una publicidad engañosa. Viene a cuenta el distingo entre "consumidor jurídico" que es aquel que adquiere, y el "consumidor material", que es quien consume, utiliza o disfruta. El acento aparece puesto en la adquisición, vocablo que comprende tanto la propiedad o derecho de dominio sobre el bien, como la posesión del mismo y también la tenencia. El término adquirir, empleado respecto de los inmuebles - casa, habitación con destino a vivienda o lotes de terreno con el mismo destino- $y$, asimismo, respecto de muebles, es usado en sentido económico y puede tener su manifestación jurídica en contratos de diversa naturaleza: compraventa, permuta, dación en pago, locación de cosa, locación de obra, etc. No olvidemos que la ley alude, indistintamente, a consumidores y usuarios.

La tutela que se otorga no atiende al sujeto particular, sino al público consumidor potencial de las cosas que se ponen en el comercio o a él se ofrecen, aunque no alcanza a quienes tienen el uso o disfrute de las cosas, bienes o servicios, de manera gratuita.

El artículo $42^{\circ}$, párrafo primero de la Constitución Nacional y el $38^{\circ}$ de la Constitución de la Provincia de Buenos Aires, no establecen requisitos o condiciones para ser considerado «usuario» y ser merecedor de la protección procesal emergente de la relación de consumo, por lo que la función o trabajo que desempeñe el presunto afectado no puede ser tenida como obstáculo para la aplicación de los principios contenidos en la Ley No 24.240 de defensa al consumidor.

Inclusive, medie o no contrato de consumo o de servicio, la tutela del Art. $42^{\circ}$ mencionado es aplicable, pues tal relación de consumo importa una calidad imperativa tanto en relación con los consumidores o usuarios, como con los prestadores de servicios o productores u oferentes de consumo. 
Aprecia Soto Castro: ${ }^{34}$ "que el consumidor y/o usuario es un nuevo sujeto social, jurídico-económico como en el pasado lo fueron el obrero, el sujeto agrario, la mujer y otros que se encuentran en una relación jurídica de desigualdad, por lo que el Estado interviene en tales relaciones, a efecto de "equilibrar" la situación, por medio de todo un sistema normativo-valorativo, establecido por leyes de orden social. Es innegable que el desarrollo de la producción en masa de bienes y la diversificación de servicios, provocan abusos en contra del consumidor, por lo que se debe dar una efectiva protección de sus derechos, para, además de hacer valer los derechos subjetivos de este nuevo sujeto social, se dé la preservación de mercado, teniendo en cuenta el interés social».

Por tanto, la fuente de las obligaciones que provoca el derecho del consumidor puede estar originada tanto en un acuerdo particular entre proveedor y consumidor, o bien de una mera declaración de voluntad unilateral expresada por el oferente de bienes o servicios. Este ofrecimiento puede ser hecho de manera directa al consumidor como por medio de la información o publicidad.

«Es una manifestación del derecho colectivo que se defiende desde las responsabilidades emergentes de la oferta. Sostiene Ovalle Favela que a través de la publicidad o de la información difundida por el proveedor, este asume expresamente la obligación de enajenar, arrendar o de prestar servicios con ciertas características y bajo determinadas condiciones. En este sentido, el proveedor hace una declaración unilateral de voluntad, en virtud de la cual asume la obligación de proporcionar los bienes o servicios a todos aquellos consumidores que satisfagan los términos y condiciones señalados en la publicidad o en la información».

\subsection{El derecho colectivo de los usuarios y consumidores}

La definición de un derecho siempre tiene como referente un destinatario. Esto es, que los derechos se piensan en abstracto (para todos), pero se resuelven en casos concretos (la individualización del conflicto). La

34 Rolando Soto Castro, El problema de la ciencia [...], op. cit. 
novedad del siglo XX fue la consagración del derecho de masas, despersonalizado, que no tenía un dueño particular ni un único afectado. Los derechos de incidencia colectiva, fueron aquellos que reconocían una parte de la titularidad procesal (la subjetividad del derecho de acción) en varios legitimados: grupos o asociaciones, Ministerio Público, Defensor del Pueblo, etc.

Las necesidades pueden ser individuales, es cierto; pero también lo es que, en el caso del derecho del consumidor o usuario fundamentalmente son colectivas o genéricas, y se integran al concepto de perdurabilidad de las situaciones aflictivas. Es decir, que aun siendo invocadas por solo uno de los afectados, existe un grupo también interesado por la magnitud de la crisis y su posible continuidad si la cuestión no se compone "para todos».

Si el interés colectivo o difuso no tiene ubicación específica en nuestro ordenamiento legal, no hay duda que se le debe abrir espacio partiendo de la base de los conceptos existentes a las exigencias de la realidad; paralelamente, las vías procesales vigentes tendrán que ser adecuadas a los fines del juego de los derechos inherentes a tales intereses.

«En el campo de los «intereses difusos» es evidente que no solo la cosa pública es la que aparece directamente dañada sino que es el conjunto de los habitantes de una manera personal y directa; respecto de ellos el derecho objetivo tiene que acordar un esquema de protección, dando legitimación para obrar al grupo o individuo que alegue su representación sin necesidad de norma específica al respectom. ${ }^{35}$

El Art. $43^{\circ}$ de la C. N., excepción hecha de las facultades que acuerda al Defensor del pueblo y a las asociaciones registradas conforme a la ley, no innova en materia de legitimación, requiriendo la presencia del «afectado», es decir, del agraviado concreto por la interferencia de un derecho o interés propio (aún cuando el texto de la Ley Fundamental no exige que el derecho tenga raigambre constitucional) al que el ordenamiento jurídico positivo confiera tutela jurisdiccional.

La norma constitucional —además de unificar la legitimación pasiva- únicamente ha extendido la calidad de sujetos exponenciales en el

35 «Ombudsman», «clase action», acción popular, acción civil pública brasileña, etc., $c f r$. Informe Anual 1988-89 de la Controladuría General Comunal de la Municipalidad de la Ciudad de Buenos Aires, p. 12. 
amparo a las asociaciones que propendan a fines ligados a los derechos de incidencia colectiva y al defensor del Pueblo (párrafo tercero), posibilitando - sin llegar a consagrar un derecho subjetivo a la pura legalidadque determinados sujetos no vinculados estrictamente a una concreta relación material puedan, sin embargo, deducir la acción.

En principio, los derechos del consumidor genérico (derecho colectivo) excluye los casos en los cuáles, los contratantes disputan el alcance de un contrato y pretendan, uno u otro mantener provisoriamente una situación de hecho. En el mismo orden de ideas se ha sostenido que el amparo no cubre los derechos patrimoniales por cuanto los mismos se hallan suficientemente protegidos por el derecho privado y la legitimación común. No obstante, tal concluyente negativa ha sido morigerada por la doctrina y jurisprudencia en función de que en ciertos casos hay que aceptar la vía del amparo, para que no queden sin protección ciertas garantías constitucionales. ${ }^{36}$

El supuesto previsto por el Art. $43^{\circ}$, párrafo $2^{\circ}$, de la Constitución Nacional presupone que el derecho o interés que aduce el afectado para entablar la acción de amparo presenta un adecuado nexo con su situación personal, que puede ser real como potencial y que no será exclusivamente de él. En consecuencia, tal supuesto no es un caso de acción popular, pues la legitimación no se reconoce a cualquiera sino a quienes participan de un determinado interés colectivo como es clásico reconocer en el derecho de los consumidores.

Ello así, aun cuando todos quienes componen una sociedad compartan el mismo interés, pues en tal caso la legitimación no se inviste por ser cualquiera de ese grupo o sociedad, sino por participar en un interés tan amplio como cuantitativamente lo es el grupo o la sociedad.

\section{III. ¿Qué es un contrato de consumo?}

Según Wajntraub, ${ }^{37}$ "contrato de consumo será todo aquel que se celebre entre un proveedor de bienes o servicios profesional y un adquirente a

36 C. Apel.CC, Azul, 1989/08/23, Voto del Juez Céspedes, in re: "Mirasur S.A.» c/ Municipalidad de Tandil s/ Acción de amparo).

37 Javier $\mathrm{H}$. Wajntraub, «Las condiciones generales de contratación y la cuestión de las cláusulas abusivas y ambiguas", en: Jurisprudencia Argentina del 17 de febrero de 1999 , No 6129 . 
título oneroso que contrate para destinar dichos bienes o servicios para su consumo final o de su grupo familiar o social, siendo indistinta su concreción o no, mediante condiciones generales".

Además, el acuerdo deberá versar sobre:

a) La adquisición o locación de cosas muebles;

b) La prestación de servicios; o

c) La adquisición de inmuebles nuevos destinados a vivienda.

Con este encuadre, la relación de consumo se establece entre quien tiene el bien o servicio, en calidad de usuario o consumidor final; y el proveedor de aquellos, sin importar en la especie que entre ellos exista una vinculación directa.

"Contrato de consumo — según Rubén S. Stiglitz- es el celebrado a título oneroso entre un consumidor final - persona física o jurídica-, con una persona física o jurídica, pública o privada, que actuando profesional u ocasionalmente, en calidad de productora, importadora o distribuidora, comercialice bienes o preste servicios, y que tenga por objeto la adquisición, uso o goce de los mismos por parte del primero, para uso privado, familiar o social».

La amplitud del concepto permite deducir la dimensión tuitiva que tiene el derecho del consumidor, en virtud de que son numerosos los tipos de contratos que se pueden celebrar donde queden vinculadas partes en calidad de sujeto consumidor y agente de producción.

¿Cuál es la singularidad, entonces?

Simplemente las diferencias que entre ellas existen para disponer sobre el objeto del negocio, sus particularidades y, en definitiva, quien tiene el poder de negociación.

Por tanto, la protección procesal se dispensa al usuario o consumidor que goza de una herramienta jurídica contra el abuso de la posición dominante.

Sostiene Alterini ${ }^{38}$ que: "cualquier cláusula abusiva emergente de un contrato de consumo, se tiene por no convenida. Es decir, que no es un problema de nulidad del acto jurídico, sino de existencia. Por lo tanto, la cuestión queda planteada no bien el consumidor introduce

38 Atilio Alterini, Contratos, Ed. Abeledo Perrot, Buenos Aires, 1998. 
la pretensión de inexistencia de la cláusula, sin que tenga necesidad de accionar mediante una demanda en los términos estrictos del artículo $330^{\circ}$ del Código Procesal».

De este modo, se impone a las empresas productoras de bienes y servicios, un deber genérico de responsabilidad que se extiende a las cosas que pone en el mercado y a las condiciones generales de contratación que pretenda establecer.

Las disposiciones de la Ley No 24.240 de defensa del consumidor establecen que, sin perjuicio de la validez del contrato, se tendrán por no convenidas las cláusulas que importen renuncia o restricción de los derechos del consumidor o amplíen los derechos de la otra parte, haciendo referencia a las formas estandarizadas de los contratos hechos en formularios, reproducidos en serie y en general a las que fueron redactadas unilateralmente por el proveedor de la cosa o servicio sin que la contraparte tuviere posibilidad de discutir el contenido. ${ }^{39}$

El contrato de consumo, entonces, no es un convenio en particular aunque pueda serlo-, sino el reconocimiento legal a las diferencias que se deben compensar entre el consumidor de bienes y el productor de ellos.

Si bien nuestra ley local no aplica un elenco numeroso de cláusulas que se deben limitar $\mathrm{o}$, al menos, controlar en forma previa por organismos o el mismo Estado, es posible sostener que mediante la política de prevención que se aplica a las relaciones de consumo, se persigue armonizar y equilibrar los vínculos emergentes, procurando anular toda posible afectación del mercado, o provocar rencillas que terminen en conflictos judiciales.

\subsection{El proveedor de bienes y servicios}

Es característica de las leyes de consumidor comparadas definir a la otra parte de las relaciones de consumo como proveedor de bienes o servicios (fornecedor, en el derecho brasileño). Es un término que sustituye las actividades del industrial, comerciante, banquero, asegurador, importador, o al más genérico de empresario.

Explica Lorenzetti: «la Ley No 24.240 (Art. $2^{\circ}$ ) complementa en sus disposiciones los términos «beneficiarios» o titulares de derechos que

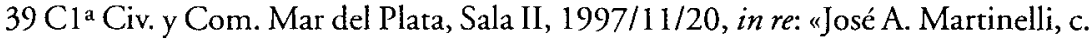
Banco del Buen Ayre», en: La Ley, Bs.As., 1998-511. 
la norma acuerda u otorga, con los "obligados», que refiere a los deudores o comprometidos. Los proveedores son "la organización" que por lo habitual pueden, usando una expresión que es a la vez jurídica y económica, traducirse como empresarios".

En consecuencia, la ley ocupa como proveedores a:

-a los obligados por la ley;

-a la índole que la "organización empresaria» puede tener tomando o no el carácter de persona jurídica;

-a la actuación bajo la forma jurídica de una sociedad o no, vale decir, tan solo como personas físicas;

-a la actividad del Estado, tanto nacional como provincial y municipal;

-a que exista, como normalmente ocurrirá, una actividad profesional o bien se trate de una provisión ocasional de bienes o servicios;

-a cualquier personaje del mercado que concurra a posibilitar una prestación: el importador del bien; el inventor o titular del derecho intelectual de marca, patente o diseño; el fabricante; el comerciante mayorista o el minorista;

-y finalmente, a la exclusión o no alcance de la normativa, dejando entonces sin la protección que brinda y sin las obligaciones que implican los negocios celebrados entre consumidores -ambos deben serlo- que tratan sobre "cosas usadas", vale decir de bienes cuya incorporación al mercado ha sido anterior, que se encuentran ya en uso.

-Asimismo, establece la exclusión de los servicios prestados por profesionales.

En pocas palabras, proveedor es aquel que facilita la introducción de bienes, productos o servicios en el mercado dejándolos a disposición del consumidor.

Sin embargo, en la cadena de responsabilidades posibles, no todos los proveedores se encontrarán en paridad de análisis, pues el que realiza la oferta como comerciante, no desliga al productor o fabricante, ni a quienes han intervenido en la red de distribución.

Por ejemplo: el último adquirente de un producto, en caso de ventas sucesivas en razón de su distribución comercial, puede demandar directamente al fabricante productor de la cadena de intermediarios por los daños causados por defectos del bien. ${ }^{40}$

40 C. N. Com., Sala A, 1999/12/29, in re: "Alberto Mydlarz c. Compañía Interamericana de Automóviles S.A.», en: ED, 189-159. 
También, el abismo que parece abrirse entre quienes, en relación con el tráfico de productos que se extiende desde el fabricante hasta el consumidor final, sostiene que: a) hay una obligación contractual de seguridad y garantía, calificada de resultado y accesoria de todos y cada uno de aquellos contratos de compraventa que ocupan cada uno de los estamentos de la pirámide que se inicia en el fabricante y concluye en los consumidores; y b) tal garantía solo se concibe a cargo del fabricante pero no de cualquier posterior vendedor de la cosa; pues se puede optar por una variante de ellas que, en vez de negar todo juicio de reproche o de admitirlo siempre, en todo caso, lo limite exclusivamente al ámbito del posible y al conocimiento del vendedor no fabricante, forzosamente más estrecho y superficial que el del fabricante o productor. Pues, solo puede volcarse sobre la casera de lata o faz externa del producto envasado y nunca sobre el defecto de fabricación o envase, salvo, por supuesto, que conociera el mismo, debiera conocerlo por su oficio o profesión o haya asumido expresamente una garantía de resultado. ${ }^{41}$

Enfrentando esta calidad, el proveedor no puede adquirir la condición de consumidor o usuario. Así lo resuelve el Art. $2^{\circ}$ de la Ley No 24.240 al disponer que no tendrán dicho carácter, quienes adquieran, almacenen, utilicen o consuman bienes o servicios para integrarlos en procesos de producción, transformación, comercialización o prestación a terceros.

«Lo que significa - dice Lorenzetti- que quedan excluidos del concepto el consumidor industrial o revendedor, ya que se hallan en el mercado en un nivel similar, o próximo, al del fabricante y compiten entre sí. En cambio, el consumidor que requiere protección es aquel que carece de intenciones que apunten a que el bien o el servicio continúen su vida económica en actividades de fabricación, producción, distribución o prestación".

En términos procesales, esta calificación que diferencia entre consumidores y usuarios frente a proveedores de distinto carácter, pero con igual identificador, significa que la interpretación en favor del más débil solamente la consigue quienes tienen la primera condición. Mientras que el

41 Cfr. C1^ Civ. y Com. La Plata, Sala III, 1983/10/27, in re: «Beatriz Caprarella de Hernández Bardi c. José Boccabella y otro», en: La Ley No 1985-D, 28, con nota de Gabriel A. Stiglitz. 
empresario también logra ese beneficio cuando actúa como consumidor final.

Ahora bien, la lectura que ofrece nuestra ley del consumidor es restrictiva, porque las normas se aplican e interpretan en las relaciones de consumo de quien contrata, circunstancia que dejaría sin protección a los vínculos de naturaleza extracontractual; ello sin mencionar el gasto que se exige para aplicar en los contratos la ley de defensa del consumidor.

Con relación al primer aspecto (tutela del consumidor por su debilidad intrínseca), la tendencia parece marcada por la Directiva 93/13 del 15 de abril de 1993 emitida por la Comunidad Económica Europea, por la cual se dice que: "es consumidor [...] toda persona física que, en los contratos regulados por la presente directiva, actúe con un propósito ajeno a su actividad profesional».

Pero el segundo motivo de exclusión (calidad profesional o no ser consumidor final) debe ser reconsiderado para dar justicia y equidad a muchas situaciones donde la interpretación justa requiere de la inteligencia judicial.

En definitiva, de lo que se trata es de precisar quienes son los beneficiarios de la ley, pero sin perder de vista que en la protección de los consumidores existe actualmente mucho de dogma y poco de práctica efectiva.

Conviven numerosos factores de desequilibrio y una ausencia manifiesta de compensaciones. Criterios como la igualdad de las partes al contratar; el mito de la convención-ley; la declaratividad constitucional; etc., son ilusiones de un tiempo menesteroso de aventuras prudentes pero arrojadas al cambio que la sociedad necesita para recobrar la confianza en las instituciones judiciales.

"El derecho y la política de protección de los consumidores, supone entonces, dice Gabriel Stiglitz, como medida inicial, el reconocimiento de la vulnerabilidad del consumidor en las relaciones de consumo, porque aun en el marco de un mercado libre y competitivo, el consumidor queda igualmente sometido, habitualmente y en los hechos, a cláusulas contractuales abusivas; publicidades engañosas; técnicas de comercialización que presionan sobre su poder de decisión, restringiendo la espontaneidad de las elecciones; a hipótesis de productos o servicios defectuosos; a obstáculos para el acceso a la justicia, etc.».

«Por eso - agrega Bourgoigne- se trata de orientar a los consumi- 
dores a reencontrar el rol y la influencia que la teoría económica tradicional les ha dado, pero que el entorno socioeconómico real de la sociedad les ha hecho perder. Tal política no limitará sus preocupaciones a reencontrar los imperativos de cualidades, de eficacia y de racionalidad exigidas por el sistema económico. Ella buscará, especialmente, corrigiendo las lagunas e insuficiencias que afectan el buen funcionamiento del mercado, a restablecer un cierto equilibrio entre los recursos y los poderes respectivos de los actores que participan del sistema; a devolver al consumidor su poder sobre el proceso de consumo, disminuyendo las coacciones que rodean el ejercicio de la función de consumir. La política es en este sentido "activa", porque, superando la sola corrección de las debilidades constatadas en el funcionamiento del mercado económico y la sola "protección" de los consumidores contra los abusos que resultan de él, ella entiende «ayudar» al consumidor a liberarse de las coacciones del consumo, asegurar la promoción de los aspectos cualitativos de las aspiraciones de vida de los ciudadanos y exigir el restablecimiento de los fundamentos de un sistema social marcado por los ideales igualitario y democrático».

\subsection{Los profesionales}

En Argentina, la prestación de servicios profesionales no admite considerar consumidor a quien solicita y utiliza de ellos.

No es esta una disposición generalmente admitida pues constituye, sin lugar a dudas, un privilegio que exime de cumplir los fines de defensa del consumidor, pensando en que el control profesional sobre el ejercicio de la actividad, y la normativa de fondo, son bastantes para cubrir las responsabilidades eventuales emergentes.

La única excepción se encuentra en la obligación de ser fieles a la oferta de servicios prometidos a través de la publicidad.

Podrá observarse que una tarea profesional se desenvuelve alcanzada por las reglas de la locación de servicios o de obra, de modo tal que las obligaciones serán de medios o de resultados de acuerdo con la naturaleza de la prestación contratada.

La actividad del veterinario que vende en su establecimiento clínico un animal a un cliente se encuentra alcanzada por las disposiciones de la ley de consumidor, pues el vínculo que lo unió al cliente es de carácter co- 
mercial y no relacionada con el ejercicio de la profesión liberal del mismo. ${ }^{42}$

Pero esta previsión normativa no es suficiente pues opera en el marco de la reparación, sin atender la diversidad de proyecciones que tienen los derechos del consumidor vinculados con el derecho a la salud y a la seguridad; el derecho a defenderse de la publicidad engañosa (esto alcanza a los profesionales) y falaz; el derecho a exigir las cantidades y calidades pactadas; el derecho de información sobre los productos, los servicios y sus características; sobre el contenido del contrato y sobre sus medios de protección y defensa; el derecho a la libertad de elección y a la igualdad en la contratación; el derecho a intervenir en la fijación de los contenidos mínimos del contrato; el derecho de no someterse a las cláusulas abusivas; a reclamar judicialmente por el cumplimiento o el incumplimiento defectuoso de los contratos; a la indemnización de los daños y perjuicios sufridos; a asociarse para la protección de sus intereses; de voz y representación en todos aquellos organismos cuyas decisiones afecten directamente sus intereses; el derecho, en fin, como usuarios, a una eficaz prestación de los servicios públicos, e incluso, la protección del medio ambiente.

«Por eso - sostiene Polo— ${ }^{43}$ todos somos consumidores, y no puede haber clasificaciones que subrayen diferencias, cuando los derechos que protegen al consumidor son generales y no admiten equivocaciones en las personas alcanzadas".

Lorenzetti, por su parte, dice: «si hay alguien obligado a cuidar la calidad de su servicio es el profesional liberal o universitario; si hay persona que deba informar a sus clientes o pacientes es este profesional, y lo mismo acontece con los abusos que puedan encontrarse en las cláusulas contractuales o los documentos que hagan suscribir a sus clientes. El control por el Colegio profesional que los matricula no nos parece suficiente o definitivo; apunta, como sabemos, a los aspectos éticos de la profesión. Tampoco es argumento de triunfo la posibilidad de accionar contra ellos civil o penalmente».

42 C. N. Fed. Contencioso-administrativo, Sala II, 1999/05/06, in re: "José María Federico Poggi c. Secretaría de Comercio e Inversiones», en: ED, 189-471.

43 E. Polo, La protección del consumidor en el derecho privado, Ed. Civitas, Madrid, 1980. 


\section{Conclusiones}

Reuniendo el perfil del nuevo derecho del consumidor con la evolución que ha tenido en Argentina desde la sanción de la Ley No 24.240 (sucesivamente reformada con las leyes No 24.568 , No 24.787 y No $24.999)$ y su decreto reglamentario $N^{\circ} 1798 / 94$, se advierten declinaciones importantes en nuestro país respecto a las posibilidades que se tienen en el derecho comparado.

El alcance que se asigna al concepto "usuario y consumidor" limita el ámbito de referentes, insertando exclusiones que no son fundadas, pues el concepto actual que tiene mayor consideración, estima que el consumidor protegido no solo es el destinatario final de los bienes y servicios objeto del contrato, sino cualquier persona que actúe con un propósito ajeno a su actividad profesional.

Sujetos pasivos, o dicho de otro modo, los alcanzados por el derecho del consumidor son todos aquellos que hayan puesto los bienes, productos o servicios a disposición de aquellos a quienes se ofrecen.

Pese a todo, no hay un concepto definido mundialmente sobre que es el consumo, propiamente dicho, y quien es el consumidor, lato sensu.

Dice Méndez Pinedo ${ }^{44}$ : «el derecho comunitario no ofrece un concepto legal sobre lo que debe entenderse por consumidor. El Tratado menciona a los consumidores de manera indirecta y en tan solo cuatro ocasiones (arts. 39 $, 40^{\circ}, 85^{\circ}$ y $86^{\circ} \mathrm{TCE}$ ), aunque estas disposiciones consideran al consumidor como un punto de referencia o el objeto de una política o medida comunitaria, pero no determinan los derechos u obligaciones del consumidor ni imponen o permiten medidas activas para mejorar la posición del mismo. Las disposiciones del Tratado, por tanto, no ayudan a definir la noción de "consumidor» en el derecho comunitario [...]. Por todo ello, habrá que considerar al "consumidor" como el consumidor final que adquiere bienes o servicios para su uso personal, no comercial ni profesional. En relación al derecho nacional de los Estados miembros, se debe mencionar que el derecho comunitario no ha seguido la tendencia del derecho danés que niega la protección al consumidor en aquellos

44 Elvira Méndez Pinedo, La protección de los consumidores en la Unión Europea, Marcial Pons, Madrid, 1998. 
casos en que el productor tiene razones para creer que aquel está actuando de manera comercial».

La interpretación judicial muestra que el derecho del consumidor nativo se recibe para dar un tratamiento tutelar, es decir, para aceptar que si se es consumidor hay una debilidad implícita a reconocer.

Los hechos manifiestan que la protección que a nivel normativo se dispensa es más aparente que real. Las soluciones, como regla, son reparadoras del daño, pero no aseguran ni fomentan la extensión del modelo a comportamientos generales del mercado. Por ello, el derecho del consumidor es más ilusión que realidad, y si lo mismo se analiza a nivel comunitario, la consagración no pasa de ser pura utopía.

Podemos advertir que en materia de acciones concretas, las posibilidades del consumidor se presentan en cuatro planos:

- reparación del bien,

- sustitución del bien,

- reducción del importe, o

- resolución del contrato de venta.

En un primer momento, el consumidor podrá exigir al vendedor que repare el bien o que lo sustituya, en ambos casos gratuitamente, a menos que ello resulte imposible o desproporcionado.

Toda reparación o sustitución deberá completarse en un plazo razonable y sin ninguna molestia importante para el consumidor.

Cualquiera de estos dos resarcimientos será desproporcionado si supone unos gastos para el vendedor que, en comparación con el otro compensamiento, no sean razonables habida cuenta del valor que tendrían los bienes si no hubiera defecto de conformidad, de la importancia de este último y de si el arreglo alternativo pudiera realizarse sin ninguna molestia importante para el consumidor.

En caso de que el consumidor no pudiera exigir la reparación ni la sustitución o de que el vendedor no hubiera dado satisfacción al requerimiento del comprador en un plazo razonable y sin ninguna molestia importante para el consumidor, este tendrá derecho a una reducción adecuada del precio o a la resolución del contrato.

En Europa, advertidos de la necesidad de aumentar la protección legal $\mathrm{y}$ fomentar un criterio de calidad en los bienes, productos y servicios a prestar al consumidor, se ha producido un reconocimiento común para dar una mayor intervención del Estado a través de la producción legislati- 
va y reglamentaria, y auspiciar que la justicia aplique con mayor rigurosidad las reglas emergentes del derecho del consumo; todo esto como una forma de responder a las necesidades de los consumidores, para un acceso a la justicia y una representación adecuada de los intereses colectivos.

Sostiene Méndez Pinedo: «[...] en Europa se ha aceptado la idea del activismo de consumo y la necesidad de movilizar un poder que actúe como contrapeso a las desigualdades que se producen en el mercado. Los principios de educación, información y asesoramiento, protección legal, defensa, recursos y representación de los consumidores no solo han sido adoptados legalmente sino que también han sido llevados a la práctica en mayor o menor grado».

Por su parte, el derecho de consumo genera un tratamiento diferente en las obligaciones de las partes. Si bien es cierto se persigue generar un sentido de responsabilidad en los procesos de fabricación o de puesta en el comercio de los bienes a consumir, también lo es que el "mercado" no consigue conciliar el enfrentamiento real que sucede entre las políticas liberales de la comercialización y la intervención del Estado en favor de los consumidores y usuarios.

No obstante, conviene recordar que Cappelletti ${ }^{45}$ sostuvo que $:$ «[...] esta afirmación no es cierta, porque el mayor obstáculo que él observa, ha derivado del fracaso de la Comunidad Económica Europea por no crear instituciones y procedimientos de coordinación para aplicar la política de protección de los consumidores (situación que tras el Tratado de Maastricht parece modificarse)".

La globalización de la economía agrega un factor más a la distorsión, y por eso, ejemplos como los que ofrece el derecho de la integración $(V \cdot g r$.: Unión Europea, Mercosur, Nafta) son en realidad promesas que distan de conseguir beneficios reales a sus destinatarios, mientras no se consiga armonizar con el contexto interno de cada legislación, y unificar los sistemas procesales de protección al consumidor.

45 Mauro Capelletti, «Formaciones sociales e intereses de grupo frente a la justicia civil», en: Boletín mexicano de derecho comparado, Nueva Serie, año XI, No $31 / 32$ eneroagosto, 1978, p. 19. 
El elemento que está cambiando de forma más sutil, y que probablemente tenga más consecuencias en la manera de comercializar de las empresas, es el proceso constante de fusión y adquisición de organizaciones, que viene a aumentar la concentración ya existente. La lista es suficientemente conocida: banca, distribución, farmacia, petróleo, entretenimiento, etc. ¿Qué consecuencias comerciales tiene que la actividad económica de un país se concentre?. La respuesta es evidente:

Negociaciones cliente-proveedor: gigantes condenados a entenderse;

- Fuerzas de ventas especializadas, más pequeñas y con más tecnología;

- Canales integrados verticalmente y con nuevas funciones;

- Precios: cuando la competencia se concentra, el consumidor paga más;

- Productos y marcas: las empresas tienden a innovar menos cuando se quedan solas, pero han aprendido que para seguir solas deben renovarse.

«Existe un supuesto en el cual la supresión de fronteras y la protección de los consumidores pueden considerarse como absolutamente complementarias. No hay duda alguna de que los consumidores pueden obtener beneficios sustanciales de la reducción de obstáculos al comercio. La integración económica, en este sentido, puede beneficiar a los consumidores al aumentar la competencia en los mercados domésticos, facilitando las economías de escala en la producción para un mayor mercado y posibilitando la reducción de precios. En este caso, estamos ante dos políticas complementarias. Ahora bien, la plena aplicación de una política de supresión de fronteras supone que las leyes y las reglamentaciones que impiden el flujo de comercio entre Estados y dificultan la movilidad de factores entre ellos son eliminadas. Aunque las medidas nacionales protectoras de los consumidores no sean adoptadas con el propósito de restringir las transacciones transnacionales pueden tener efectos indirectos sobre el comercio y la libre circulación de los factores de producción. La diversidad legal también supone un obstáculo. Cuanto más diversas sean las normas nacionales en un mercado común, más costoso resultará para el vendedor distribuir y comercializar en los mercados nacionales integrantes de ese mercado común. En estos últimos supuestos, la liberalización del comercio realizada a escala comunitaria puede perjudicar seriamente a los consumidoresm. ${ }^{46}$

46 Elvira Méndez Pinedo, La protección [...], op.cit. 
En resumen, el derecho del consumidor en Argentina abrió horizontes y esperanzas a un sector muy importante de la sociedad que bajo el rol de usuarios y consumidores lograron equilibrar, desde la normativa, las diferencias de poder negociador en las relaciones de consumo.

Aunque la ley importa un marco acotado que cuenta beneficiarios poco claros y exclusiones incomprensibles, ha significado la instalación de derechos sustanciales que permiten imponer principios y presupuestos que cambian las reglas tradicionales de la contratación y sus obligaciones consecuentes.

Este nuevo derecho del consumidor debe colegirse por los jueces. A estos les cabe interpretar la axiología y, por supuesto, comprender que ante situaciones litigiosas las reglas tradicionales del proceso común no pueden aplicarse, ipso facto.

Tanto la reforma constitucional, como el nuevo derecho de amparo que surge del artículo $43^{\circ} \mathrm{y}$, en especial, las disposiciones del nuevo artículo $42^{\circ}$, emplazan una lectura que no se pueden soslayar.

Los procedimientos donde se resuelvan derechos del consumidor son procesos constitucionales, y así habrá que interpretarlos con su lógica y consecuencias.

\section{Bibliografía}

Almagro Nosete, José - Tomé Paule, José. Instituciones de Derecho Procesal. Tomo I, (Proceso Civil, 1), ed. Trivium, Madrid, 1993.

Almagro Nosete, José. Constitución y Proceso. ed. Bosch, Barcelona, 1984. Barbosa Moreira, José Carlos. "La legitimación para la defensa de los intereses difusos en el derecho brasileño» en: Revista Jus, No 34, p. 61. Barrios de Angelis, Dante. Introducción al estudio del proceso. ed. Depalma, Buenos Aires, 1983, pp. 129 y 171.

Bujosa Vadell. La protección jurisdiccional de los intereses de grupo. ed. Bosch, Barcelona, 1995.

Caso Ekmekdjian, Miguel A. "cl Sofovich, Gerardo" en: La Ley, 1992-C, p. 543 y ss; Rev. El Derecho, 148-354. Entre otras, ver: Polino, Héctor y otro c/ Poder Ejecutivo, C.S., P. 304, sentencia del 7 de abril de 1994, en: La Ley, 1994-C, pp. 291 y ss. con nota de María Angélica Gelli, Reforma constitucional, control judicial y proceso democrático. 
Causa B 47.764, "Fernández Arrese», 20/5/80, DJBA, 119:485; y especialmente causa B 49.544 «Toman», 7/12/84, disidencia del Dr. Héctor Negri.

Causa B.55.392, «Rusconi, Oscar c/ Municipalidad de La Plata s/ demanda contencioso-administrativa" en: Revista Actualidad en el derecho público, $\mathrm{N}^{\circ} 2$, set/dic. 1995, p. 23 y ss.

Colaço Antunes, Luis Felipe. A tutela dos interesses difusos em direito administrativo. Ed. Livraría Almedina, Coimbra, 1989.

Bricola, F. "La tutela degli interessi colletivi nel processo penale» en: Le azione a tutela di interessi colletivi, Padova, 1976.

Fairén Guillén, Victor. Ensayo sobre procesos complejos. La complejidad de los litigios. Ed. Tecnos, Madrid, 1991.

Farina, Juan M. Defensa del consumidor. Ed. Astrea, Buenos Aires.

Flah, Lily y Smayevsky, Miriam. «Legitimación de los titulares de intereses difusos» en: La responsabilidad, [obra conjunta de homenaje a Isidoro H. Goldenberg] op. cit., p. 401.

Gelsi Bidart, Adolfo. "El Derecho Procesal y la protección al consumidor" en: Revista Uruguaya de Derecho Procesal No 1, 1978, pp. 11-25.

Ghersi, Carlos. Modernos conceptos de responsabilidad civil. Ed. Ediciones Jurídicas Cuyo, Mendoza, Argentina, 1995.

Gozaíni, Osvaldo Alfredo. La Justicia Constitucional. Ed. Depalma, Buenos Aires, 1994.

El Derecho de Amparo. Ed. Depalma, Buenos Aires, 1995.

Kemelmajer de Carlucci, Aída y Tavano de Aredes, Josefina. "La protección al consumidor en el derecho comparadon en: Derechos del Consumidor, $\mathrm{N}^{\circ} 1$, ed. Juris, Rosario, 1991.

Lorca Navarrete, Antonio. El problema de la administración de justicia en España. Ed. Instituto Vasco de Derecho Procesal, Bilbao, 1989.

Nigro ,M. Giustizia administrativa. Ed. Il Mulino, Bologna, 1979.

Mosset Iturraspe, Jorge. «Los nuevos derechos: ¿meras declaraciones o derechos operativos?» en: Revista de Derecho Privado y Comunitario No 7; ed. Rubinzal Culzoni, Buenos Aires, 1994.

Silguero Estagnan, Joaquin. La tutela jurisdiccional de los intereses colectivos a través de la legitimación de los grupos. ed. Dykinson, Madrid, 1995.

Acuña, Marcela Soria y Suárez, María Eugenia. «Derechos colectivos y difusos. Legitimación para accionar en su defensa» en: Doctrina Judicial 2001-3, p. 1131 y ss.

Vigoriti, V. Interessi colletivi e processo. La legitimazione ad agire. Ed. Giuffré, Milano, 1979. 
Zannoni, Eduardo. "Derecho subjetivo e interés simple en la responsabilidad civil» en: La responsabilidad. [obra conjunta de homenaje a Isidoro H. Goldenberg], ed. Abeledo Perrot, Buenos Aires, 1995. 